\title{
A vision of and for love: Towards a Christian post-postmodern worldview
}

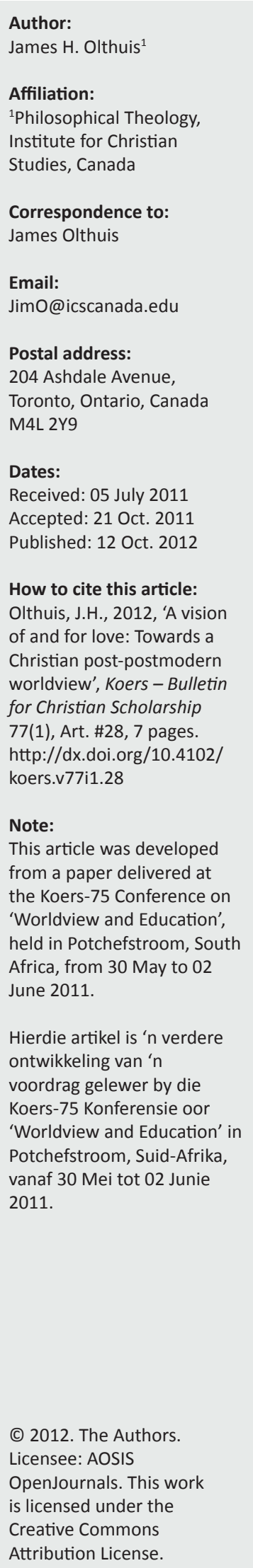

The theme of this article has to do with the identification of distinctive features that need emphasis in a biblical worldview attuned to the postmodern world of the 21st century. The first of these features is the embrace of difference as non-oppositional, as challenge to meet, rather than a threat to resist. The second is that with a postmodern understanding of the existence of limited rational knowledge (Reason and Science) and of the crucial role of faith, worldviews need to be seen, not in the first place as conceptual systems, but as faith-oriented, sensory expectancy filters, operating implicitly and largely beneath our conscious awareness. The third is the recognition that responsibility-to the other rather than freedom-from the other needs to be emphasised. Such responsibility involves recognising that voluntary sufferingwith the other is crucial to a post-postmodern biblical worldview. Indeed, the final feature proposes that such a worldview needs to be rooted and grounded as a vision of and for Love. As God is Compassionate Love, and as God is with us (Emmanuel), so we, image-bearers of God, are to embody love and resist evil, living out our confession that we live by Grace and not by Blind Chance.

'n Visie vir en van liefde: Op weg na 'n Christelike post-postmoderne werklikheidsvisie. Die tema van die artikel was die identifisering van die onderskeidende kenmerke wat beklemtoon moet word in ' $n$ bybelse werklikheidsvisie wat ingestel is op die postmoderne wêreld van die 21ste eeu. Die eerste van hierdie kenmerke is die omarming van verskil as nie-opposisioneel, as ' $n$ uitdaging om te ontmoet eerder as ' $n$ bedreiging om te weerstaan. Met ' $n$ postmoderne verstaan van beperkte rasionele kennis (Rede en Wetenskap) en van die kritieke rol van geloof, is die tweede kenmerk dat werklikheidsvisies nie in die eerste plek gesien moet word as konseptuele sisteme nie, maar as geloofsgeoriënteerde, sensoriese verwagtingsfilters wat implisiet en grootliks onder ons bewuste besef werksaam is. Die derde kenmerk is die erkenning dat verantwoordelikheid-teenoor, eerder as vryheid-van die ander beklemtoon behoort te word. So ' $n$ verantwoordelikheid behels die erkenning dat vrywillige 'ly met' die ander beslissend is vir ' $n$ post-postmoderne bybelse werklikheidsvisie. Die laaste kenmerk stel inderdaad voor dat so ' $n$ werklikheidsvisie gewortel en gegrond moet word in ' $n$ visie van en vir Liefde. Net soos wat God Medelydende Liefde en God met ons is (Emmanuel), so behoort ons liefde te beliggaam en boosheid te weerstaan en so ons belydenis, dat ons deur Genade en nie deur Blinde Toeval leef nie, uit te leef.

\section{Introduction}

For 75 years, Koers, from its base in South Africa, has championed the crucial importance of a reformational worldview in science and in education throughout the world. When Koers began publishing, worldview was neither a widely used nor a widely understood concept. Now, 75 years later, the notion of a worldview is both commonly recognised and broadly deployed in a wide variety of academic as well as non-academic contexts throughout the world. With the growing realisation that there are no innocent, unbiased ways of looking in the world, that everyone wears glasses and looks at the world through a particular lens, window or frame, the idea of worldview has become common currency.

At the same time, the growing recognition of the usefulness of the concept has turned out to be a mixed blessing. On the one hand, although it is now generally acknowledged that everyone comes outfitted with a wide array of pre-judgements, that everyone has built-in biases, worldviews are frowned upon, even anathematised, because they are considered euphemisms for ideologies with their dogmatism. We need, it is said, to move beyond such exclusivism into an era after worldviews. On the other hand, the recognition that all knowledge is perspectival, worldview-ish, rooted in a particular historical and cultural setting, rather than universal or absolute has raised fears of an 'anything goes' relativism. Truth, it is feared, is being dismissed or, at least, certainly compromised.

It is this high stakes context, on the occasion of Koers' anniversary, that gives rise to the theme for this article: How best do we advocate - and if necessary, rework or recalibrate - a biblical 
worldview in our postmodern world of the 21st century? Indeed, I will be working towards the formation of what I will be calling a post-postmodern Christian worldview.

Despite the debacle of World War I, when Koers began publishing, Modernism with its faith in reason, science and technology as the singular, linear, inexorable and progressive forces for health, knowledge, continual growth and success was still in full bloom. However, as the twentieth century unfolded - for a complex of reasons of which the Holocaust is emblematic - Modernism's hope and faith in the power of reason and science to deliver freedom, security and happiness withered and wilted. Despite unparalleled advances in almost every field of human endeavour, especially technology, our city streets are filled with the hungry and the homeless, violence and war continue to plague us, we are running out of the basic elements necessary for life: clean air, good food, stable currencies, caring families, intimate friendships, vibrant churches. Underneath we are at un-ease, running scared, something, we fear, is seriously amiss.

In its place, both parasitic on Modernism, even as it is a spiritual resistance movement - a para-site - to Modernism, a new Zeitgeist or Stimmung which we now call Postmodernism has unmistakeably crept in like a fog with its own smell, feel, and touch. Almost everyone senses that something novel is astir, and gathering force, but like a perfume sprayed in the air where one cannot determine where the scent begins and ends, Postmodernism can be characterised but not defined. In its cultural use, Postmodernism typically has a wider range than in its philosophical deployment; yet, even philosophically, Postmodernism functions as an umbrella term covering a variety of paradigms.

At the same time, there are a number of common characteristics or family resemblances in a postmodern ethos that stand out and can be circumscribed. However, because many Christians, including many theologians, respond nervously and negatively to Postmodernism, identifying it more or less with relativism ${ }^{1}$ if not nihilism, I want, at the outset, to be upfront with my conviction that Postmodernism need not be seen as an enemy. In fact, in this article I will be arguing that, in a number of important aspects, Postmodernism is more a boon than a bane to the cause of Christ. Indeed, as I see it, there are certain cardinal features of Postmodernism that deserve to be recognised, honoured and accounted for in a Christian worldview - even if, in terms of the Gospel, they will be revised, even radicalised, in what I want to call a postpostmodern biblical worldview.

\section{Embrace of difference}

In contrast to Modernism's suppression of difference, the most distinctive feature of Postmodernism is its desire to embrace difference. For Modernism, difference is by the

\footnotetext{
1.For instance, even a highly respected, sophisticated biblical scholar such as Richard Bauckham $(2002: 64,62)$ talks of 'postmodern relativism' that reduces 'all truth Bauckham (2002.64, 62) talks of "postmodern relativism' that reduces 'all truth claims to preference, because 'there is no basis on which to argue or persuade'. In contrast, for Jacques Derida, perhaps the most influential postmodern philosopher, the crucial point is not that truth claims are finally matters of preference, but the very different claim that there are no airtight, knockdown arguments for Truth. In the end, we live by faith.
}

nature of the case always oppositional, in Hobbes's words, 'the war of all against all'. According to Freud, Hegel, and Sartre - three of Modernism's most influential thinkers there are only two possibilities: dominate or be dominated. In Sartre's worldview, the other person is hell because the gaze of the other person turns us into an object. For Freud, love of neighbour is only possible at the expense of love of self. There is either inclusion in sameness or exclusion in otherness.

In ethical Postmodernism, difference is not the enemy, a threat, defect or deficit which needs to be controlled, bracketed, or eliminated, but a challenge to connect with, attend to and honour. The proper relation to the other person is deference, rather than domination, condescension, dismissal, or persecution. Genuine community is being together in difference and diversity, rather than marginalisation or fusion into sameness - in, through and despite adversity.

In our pluralistic, multi-faith global village, the honourable and respectful embrace of difference is the greatest challenge facing our postmodern world. We urgently need to develop a model of non-oppositional difference, an economy of love in which power-over (with its opposition to the other) is replaced by power-with (mutual recognition, attunement and empowerment). Love of self and the other is not oppositional, but correlational. Loving the other enhances the self, hating the other diminishes the self (Olthuis 1997:146-151). However, no matter how promising the idea of non-oppositional difference, in our fallen world the everpresent economy of violence makes it extremely difficult, often virtually impossible, to put into practice. For it is only when we are secure in our own identities, firm in our faith, that we are enabled vulnerably to run the risk of suffering violence that attends all efforts to respectfully connect with the other and different. Whether on account of previous hurt that gives rise to fear, the guardedness that comes from ignorance, or unattended anger, there lurks in all of us the impulse to control, domesticate, dismiss, or even eliminate difference.

However, a post-postmodern biblical worldview needs to be hospitable to and respectful of difference. That is the biblical mandate:

When an alien lives with you in your land, do not mistreat him or her. The alien living with you must be treated as one of your native-born. Love him or her as yourself, for you were aliens in Egypt. I am the Lord your God. (Lv 19:33)

At this juncture in history, and intrinsic to the practice of neighbourly love, it is particularly incumbent on us as Christ-believers to give shape and contour more keenly to an economy of love as the only possibility of escaping the pernicious economy of violence that so often seems inescapable. The more we forthrightly and enthusiastically shape, work out and publicise such an economy of love as inherent to our understanding of what it means to be Christian, the more religion could become, not a conversationstopper as Richard Rorty claimed and Modernism believed, but a conversation starter. 
We would do this not to exclude others or prove that our way is the only true way, but to give witness of how and why - rooted and grounded in our vision of God as a God of Love - we see things the way we do, how we conceive of justice, how we practise mercy. Along those lines and in that way, we invite others in turn to share their deepest beliefs and convictions for mutual learning and benefit. For the big question for all of us as world-citizens, whether Christian, Buddhist, Moslem, Marxist, Humanist, Hindu, Atheist, whatever, is how to sort out good worldviews - justice serving, mercy-effused, difference-embracing, life-affirming visions - from worldviews that do not serve justice, that exclude the other and different, that fuel discontent and feed greed. The sustainability of our planet, with its flora, fauna and peoples depends on such inter-faith negotiation. I say negotiation, because, for the stakes involved, conversation is far too mild a word.

That slow, often tedious, back and forth process of coming to know and respect each other which belongs to an economy of love, does not, as we only know too well, eliminate the risk of violence. The risk factor is inherent in the dynamic of love. However, an economy of love - risky and precarious as it is - provides the only alternative for meeting in the middle, for non-violent connections. Thus, although in our broken world it is difficult and risky to walk humbly and justly with those who are different and strange, it is not and need not be, in God's grace, impossible.

The entire fragile process, fraught with apprehension and anxiety, facing prodigious odds, the 'rainbow nation' of South Africa, with its multitude of ethnic groupings and eleven official languages knows only too well. When I visited South Africa for six weeks in 1980, I never dreamt that in 15 years apartheid could or would be dismantled without a sea of bloodshed. Yet it happened. And today South Africa is continuing to live out that miracle of forgiveness, truth and reconciliation, however imperfectly, in fragility, with lapses, on the way. The rest of the world stands in awe of the courage, dedication and grace that South Africa exhibited. Indeed, in this communal process of working-out and livingout a biblical worldview that embraces difference with justice and mercy, the Christian churches and communities in South Africa deserve to play a very important and distinctive role.

\section{A limit to knowledge}

Another positive distinction of Postmodernism is its dethronement of Reason. Reason is put in its place. This is big stuff, because Modernism placed supreme confidence in Reason (and Science) as the Answer to all of life's problems, the royal road to knowledge, security and happiness. The ethos of Modernism is mastery, control and independence. Modernism asks: 'What's the problem?' And then it says, 'Let's solve it! After all, we have the technology and knowhow. Any and every mystery - including the mystery of God - will eventually yield its secrets if we persevere.'

Postmodernism not only considers the claims of Reason illusions that need to be unmasked, but marks them as dangerous to people everywhere. In the public arena,
Modernism insisted that we bracket, deny, or ignore the very key characteristics which make us unique. We were asked to keep our differences - of gender, race, and faith - at home, personal and private. In brief, Reason neutralised the other, with philosophical thinking in the West 'in essence' attempting 'to domesticate Otherness' (Gasche 1986:101), achieve unity and effect closure. Emmanuel Levinas (1969:46) argues that the modernist credo of mastery and control is 'totalizing', resulting in a 'philosophy of injustice'. The upshot has been that the ruling elites have passed off their own agendas as the voice of reason, often with the insidious consequence that the different and other, the less positioned and unprivileged, particularly the weak, the marginalised and the poor - those whom the Bible calls the strangers, widows and orphans - are set aside and, if they resist, face discrimination and retaliation.

Life, says Postmodernism, is more than logic. Not that there is no place for science and reason; there is, lots of space, and there are many accompanying benefits. But there is a limit to knowledge and knowledge is never disinterested, neutral, atemporal, or aspatial. There is no such thing as Universal Reason. Reason is never impartial. Reason is always in service of wider and broader interests. In other words, knowledge only reaches so far. Indeed - in shades of Augustine Jacques Derrida (1993:29) ends his Memoirs of the blind with an emphatic confession: 'I don't know. One has to believe.'

Moreover, because human understanding is embedded in the very phenomena we are trying to understand, there are no independent means of verifying the correct paradigm. There are no knockdown, airtight logical arguments that go all the way down, proving a certain position as the unvarnished Truth. Grand narratives that claim to explain everything have lost credibility. No theory, no science will ever be able to encompass reality.

I think it is important to note the significance of the postmodern limitation of knowledge for our advocacy of a biblical worldview. In the period of Modernism that developed in the West after Descartes, worldviews, including Abraham Kuyper's Calvinist world-and-life view that has been of such tremendous consequence to us, developed under the primacy of intellectual thematisation. Perceptions of the world were identified with, and in the process transformed into, world-conceptions. Worldviews emerged as a framework of conceptualised beliefs, often defined as a set of dogmas. In other words, for the most part, worldview as an idea is still very largely intellectual, conceptual and rational. This perception is in fact so strong that Jamie Smith, a leading young Calvinist philosopher at Calvin College, suggests in his Desiring the kingdom that we replace the concept of worldview with Charles Taylor's idea of the social imaginary (Smith 2009:63-71).

Indeed, as I read it, it is a major question whether what could be called the worldview ship can be pried loose from its intellectual moorings and retooled to do service in the often uncharted and tempestuous seas of faith and life. My wager 
in response to this question is this: Yes. When world-viewing is acclaimed as fundamentally an activity of faith, playing a valuable role in the formation of God-and-neighbourhonouring embodied practices and habits in which the goal is not right thinking but right living, worldview is still a crucial and serviceable concept. Understanding a worldview as a faith-qualified, psychically founded configuration places the emphasis on its sensory foundation rather than on ideas and concepts. In world-viewing, the always present logical distinguishing is subsumed and tacit rather than explicit and conceptually focused. Which means that a host of nonrational, unconscious, and implicit ways of knowing play paramount roles in the formation and function of worldviews. In our postmodern world, it is the role of these implicit ways of knowing that require more focused attention.

\section{Implicit knowledge}

World-viewing or visioning is a complex, developmental two-way learning process. A worldview is the pre-conceptual orienting lens or glasses in and through which we reach out to the world even as the world impinges on us. Coming into the world in interaction with parents and environment, children learn how to see in order to make their way in the world. Through their eyes, children not only learn to take in the world as they learn to focus, identify and recognise a host of shapes and things, but simultaneously, they develop expectancy filters that crucially affect not only how and what they identify and recognise, but how they respond and react to what they see. In other words, a worldview is not only a vision of the world, but it is at the same time a vision for the world. If our eyes are myopic, if our eyes are teary or our glasses are tinted, what we see will be myopic and tinted even if we are unaware of the tint, tears, or myopia.

Moreover - and this is our main point - it is important to recognise that world-viewing and worldviews are about much more than seeing and vision. All of our senses are involved. We see, but also feel, touch, smell our way through the world. An intuitive sensorium - a panoply of senses develops which implicitly aids and abets our orienting. Indeed, even if it is implicit, operating largely beneath our conscious awareness, we sense our way through the world as much, if not more, than we think our way through. Thus, what we have called a worldview is as much a matter of the imagination as of the intellect, as much unconscious as conscious, involving world-feeling, world-touching, world-smelling and world-hearing. It is by our implicit, often inarticulate awareness of our intuition - Heidegger's Befindlichkeit - by our bodily attunement, by our learned physical, emotional and moral reflexes, that we make our way in the world. Recognising the role of all our senses in finding our way in the world suggests that we would do well to talk of world-orienting rather than world-viewing.

The importance of attending to the sensory foundation of worldview formation is today underlined by the most recent developments in the area of brain research. Neuroscientists have discovered that we process knowledge in our brain in at least two ways - what has been called the 'high road' of words and logic and the 'low road' of emotions which involve different circuits in the brain (Goleman 2006; LeDoux 1996). The low road, involving the bottom and right part of the brain, processes in a non-linear, sub-symbolic code. In other words, we actually know a lot more than we can say in words. The high road, involving in particular the cortex, or top part of the brain, is linear, logical, language-based and conscious. These two 'roads', the conscious and unconscious, relate and interrelate in a knowledge spiral. For example: one can end up feeling totally stuck in efforts to solve a problem logically, only to experience a breakthrough when turning away, letting go and giving up. Letting go lets the unconscious do its work, prepared by all the analytic work. Then, one takes the breakthrough and works it through consciously, testing it, calibrating it in a process of integration. And even as there is implicit and explicit knowledge, there is implicit and explicit memory. Gut-level memory is recorded or packaged in a non-verbal code of emotions, perceptions and bodily sensations. To mention one example, our bodies remember how to ride a bicycle without conscious attention.

In similar fashion, much of our relational knowledge is encoded in emotional meaning-patterns which act as expectancy models or attachment filters that henceforth predispose how we experience relationships automatically and without our even knowing it. We are aware of what we experience, but not of the filter itself through which we experience. Psychologists have identified four common attachment filters (Coe \& Hall 2010:240-259): Secure (able to trust others and be open to the world), Pre-occupied (engrossed in efforts to get their needs met, inattentive to the needs of others), Dismissing (expect nothing, disconnected from self and others) and Fearful (needs closeness, afraid of closeness). These attachment filters, acting below our conscious awareness, giving shape to how we feel about ourselves, helping us make sense of our lives, God and others are, in fact, what we call worldviews. When, as a young infant, I feel seen and heard as lovable and worthy, I develop a secure attachment and I am primed to be open to the world. However, when things go seriously wrong developmentally, I do not feel seen and heard and negative attachment filters develop which make me 'naturally', reflexively, even if unawares, pre-occupied, dismissive, or fearful.

These fundamental moods, patternings, or filters formed in early childhood experience, continue to to play an indispensable and inextricable role in our later efforts to explicitly thematise and conceptualise our worldviews. If early formation is good enough, if the attachment filters are 'secure', there will tend to be a good-enough, continually recalibrating, mutually interactive fit between the explicit knowledge of a love-oriented, other-affirming worldview and our implicit gut knowledge. There will develop a double two-way movement: the implicit and explicit worldviews will interact dynamically and integrate in a positive growth spiral. The expressed and confessed worldviews will not only find embodied resonance in the implicit gut knowledge, 
but they will act to encourage, direct and support explicit rituals, routines and rhythms in daily life. In that way, worldviewing can play an indispensable role in the coming into being of liturgies of love, both personally and interpersonally in marriage, family and friendship, but also interpersonally, nationally and internationally.

However, if the formed attachment filters are fearful, dismissive and preoccupied rather than secure, there will be strong, if implicit, resistance to adopting and living out a love-oriented, other-affirming worldview. More than that, there will be deep-seated impulses to thematise worldviews which justify and thus rationalise our fears and dreads. Unless these (often justified) resistances are worked through, adherence to the articulated worldview will tend to be halfhearted lip-service. The result is often Christians who feel deeply inadequate, afraid that their Christ-confession is shallow, and are therefore prone to depression.

In this context, it seems imperative to me that worldview theorists and worldview educators need to give more substantial and focused attention to the role and function of our attachment filters, not only in explicit conceptual worldview elaboration, but in how they act to support or work against living out the confessed explicit worldview in the push and pull of daily life. For if the early emotional injury and the attendant fearful filter formation is not attended to adequately, people can easily be thrown into easily into bouts of depression, guilt, shame, or numbness. We have long known that a worldview crisis can be brought about by the gap between worldview and experience. Now we are in a better place to appreciate that a worldview crisis can also be brought about in the clash or lack of fit between our implicit emotionally based worldview and our explicitly confessed and articulated worldview. This further indicates to me that worldview educators need to be more alert to the reality that education in world-orienting - world-viewing - is an implicit dimension of all formative exercises, particularly in family, school, church and community. Worldview education needs to be an interdisciplinary undertaking including not only theologians and philosophers, but also parents, counsellors, ministers, teachers and community workers.

\section{Wisdom is more than knowledge}

The postmodern understanding that there is a limit to knowledge also serves as a trenchant reminder that wisdom is beyond and different from rational knowledge. Which ought to serve as an inspiration for us to work for the recovery of philosophy as the love of wisdom, in order that philosophy, as Emmanuel Levinas (1981:62) suggested, may be the 'wisdom of love at the service of love'. That means that we ought to say, along with Jean-Luc Marion (1992:472), ama ut intelligas [love, so that you might understand]. That indeed is the underlying theme in this article: where there is love, there is vision ('ubi amor, ibi oculus') (Jüngel 1983). A biblical philosophy of worldview would be 'working love conceptually (and hence, in return, working the concept through love)' (Marion 1991:47). Reason, transformed by and in the service of love, will then have an eye for difference not in order to close it down or marginalise it, but in order to approach and connect with it, and let it be. Love, in this understanding, is not an auxiliary to the order of reason. There is only one order, the Order of Love, with reason as one of its dimensions.

\section{Faith and things unseen}

Postmodernism attends to and makes room for the invisible, the unconscious, the emotional, all the non-rational ways of knowing; not as second-rate, subservient, irrational forces to be repressed, feared or discounted, but as necessary, indispensableco-contributorsin themultidimensional process of human development. That includes faith, or, as I like to say, in order to indicate its functioning as a process, faithing. Postmodernism recognises that everyone lives by faith. Jacques Derrida was insistent that logic and argumentation are never able to erect airtight closure. There comes a limit to the reach of rational knowledge. Whereas for Modernism, being neutral, without presuppositions or prejudices, was the order of the day, Postmodernism champions the fact that we all begin somewhere, from someplace, with a certain fix on reality. None of us begins from a position of innocence. Prejudices are not all bad. In fact, we cannot avoid them. In reality, one of the most harmful prejudices is believing that it is possible to be unprejudiced because then, (purportedly) on the side of Truth, I may insist with impunity that others agree with me and reprimand, even persecute them, if they do not. As Heidegger and Gadamer especially brought to the fore, pre-judgements are the frames, the pictures - the worldviews - from which and through which we see the world and make sense of it. We all begin and end in the surrender of faith. Now, from our differing vantage points, we are called to negotiate, working together for justice with compassion, mercy with truth.

Whereas for Modernism, the fact that God is unthinkable, unprovable and unpresentable proved the irrationality, inadequacy and irreality of faith and God, for Postmodernism, the same features point to an excess beyond the reaches of reason. Suddenly the reality of God in the universe is no longer so outrageous. Suddenly there is authentic space for faith, miracles and grace. No longer, in a postmodern world, can people of faith - in our case the Christian faith - be dismissed curtly as prejudiced because they champion their faith. Now they (we) can enjoy participating in the public arena as spokespersons of faith.

\section{Responsibility}

For Postmodernism, everything is relational and contextual. The invisible and non-rational, as we have indicated, is just as important as the visible and the rational. What is not said is just as important, if not more so, than what is said. The margins bleed into any text, just as the body of a text bleeds into margins. Hard and fast definitions, absolutes, 
do not exist. Stories or narratives are the woof and warp of the human experience, always on the go, in process, on trial. However, this does not mean relativism. Rather, the fact that creation is in process, on trial, on the way - and this deserves underlining, indeed headlining - is an ethical call to increased vigilance. Every decision we take makes a difference - whether for good or for evil. Responsibility, in Postmodernism, is once more front and centre.

Whereas in Modernism, 'freedom-from' is the first word, Postmodernism insists that, before anyone says yes or no to the call of the other, we are already summoned to be responsible for the other. The face of the other, says Jewish philosopher Emmanuel Levinas, convicts us, calling us to responsibility (Olthuis 1997). As a result, in contrast to Modernism's focus on solving the problem in order to maximise individual freedom, the ethos of Postmodernism is: listen to the singular who! See the suffering. Respond! Be wary of the human propensity for violence and evil including our own. Act justly with compassion without any pretensions that we have the final solution. And pray without ceasing! Looking at responsibility as the first word reinterprets freedom, not in terms of being free from, but, in biblical terms, as being free to love and minister to the other.

This ethical call to responsibility is not only congenial with the ethos of the Gospel, as I read it, but it also challenges us to readjust and refocus our worldview formulations. In our usual articulations of a reformational worldview, the place and role of suffering has not been given the place and attention that it deserves. There is a pressing need for that to change.

I still remember with surprise and shock when I read, as if for the first time, that we are 'heirs of God and joint heirs with Christ - if, in fact, we suffer with him ...' (Rm 8:17). Then, my eyes opened, I discovered that this theme of suffering with Christ is underlined and highlighted by Peter and Paul. Peter encourages us, 'if you can have some share in the sufferings of Christ, be glad ...' (1 Pt 4:13). Paul, in Philippians 3:10, challenges his readers to imitate Christ by sharing in his suffering by becoming like him in his death if somehow we may attain to the resurrection of the dead. In Colossians 1:24, we are called to be part of Christ's continuing ministry of compassion, 'completing', as did Paul, 'what is lacking in Christ's afflictions for the sake of his body, that is, the church'. And, particularly in view of the current environmental crisis, it is important to recall that Paul, in Romans 8, goes on to tell us that the entire creation is 'groaning in pain' awaiting on tiptoes, as it were, for the revelation of the sons and daughters of God.

Jesus, in Matthew 25, gives us a clue as to how we are to suffer with him. The righteous, he reports, will ask: When did we feed you, visit, or clothe you? Then, the 'King will answer, 'Inasmuch as you did this to one of the least of these brothers and sisters of mine, you did it to me.' As God is compassionate, and as God is with us (Emmanuel), so we are to be with others. As God suffers with those who suffer, we are called to suffer-with. In contrast to involuntary sufferingfrom that we all undergo, it is crucial to understand that we are called to a suffering-with. Suffering-with is a voluntary act in which there is the liberating power not only to resist suffering, but also to redeem creation. With-ing is the way to be, it is the way of love (Olthuis 2006). Right in that sentence, I see the beginning of a Christian post-postmodern worldview. Not fusion with the other, nor abandonment of the other, not rescue or persecution of the other, but being with the other in blessing, suffering-with and celebratingwith. Each day anew we are to work out our salvation with fear and trembling, for God is at work in us.

Whereas Modernism seems fixated on its need to control, dominate and exploit reality with all its attendant oppression and injustice, Postmodernism, with all of the positive features that I have noted above, is nevertheless so impacted by the unspeakable atrocities that afflict us, so mesmerised by the human penchant for evil, that, even as it works for and longs for the coming of justice, it seems captive to the fear that, finally, we live only by Chance and, in the end, there is only death.

\section{God: Trinity of Love}

Right at this juncture in human history, it strikes me that there is a novel and abundant opportunity for Christians to confess anew, that because God is Love and that Love is stronger than death, we live, not by Fortune or Blind Chance, but by Grace and Truth. Such a vision of and for Love encapsulates the heart of what could be called a Christian post-postmodern worldview. It is a vision we bear witness to in all humility, not as those who possess the truth, but as those who, overwhelmed by the depth and width of the Love of God which they experience, are eager to invite others to share and join in.

God is love itself, ipsum amore. Only as communion can God be at all: that is, as the Trinity of Love. Out of the overflowing of the excess and passion of Love itself the creation came into being. Eberhard Jüngel (1983:327) says it well: God is Unoriginate Origin because God 'alone can begin to love without any reason, and always has begun to love'. God alone, as creator, does not have to be loved in order to love. God as Love is the origin of love. Love is therefore not a property of being. Love is the very mode of God's existence. If God is love, creation will be. If God is love, God could not be God without creating. 'To be God is to be Creator of the world' (LaCugna 1973:355). God as Love seeks the other, disseminating, overflowing. With-ing is God's passion. Compassion is God's best name. God-with-us is who God is: Love. And because God is creator of the world ex amore (Olthuis 2008:155-170), the ultimate dynamic of the world is also to be found in love. We find our identity through participating in the divine dynamic of love. We are called to love in response to being loved (gifted) into existence. 
God's love is the 'yes more "ancient"' that Derrida (1992:296) championed, the Yes we are to iterate and reiterate in our lives. Amen, Amen. So let Love Be. That is the constant refrain which needs to sound and resound in, under and through all biblical worldviews regardless of diversity of language, culture and emphasis. Let Love come is a yes-saying that bears witness - witness calling to witness, testimony to testimony - across the abysses that divide us from one another. Bearing witness in this way is an event testifying to the blessing and gifting that is life in God's world.

To love or not to love: that is the question. Taking seriously that we are gifted and called to be image-bearers of God who is Love deepens immeasurably the meaning and scope of the mandate in Genesis 1:28 to 'be fruitful and multiply, and fill the earth and subdue' it. Whatever we do - sexually, culturally, institutionally, environmentally - we are to fill the world with the glory of God's presence - that is God's love - so that love has dominion. 'The earth is the Lord's and the fullness thereof', confesses David in Psalm 24:1. That fullness is love, the very fullness (the pleroma) that Paul confesses in Colossians 1:19 dwells in Christ, the 'fullness' of which we have all received, 'from grace to grace' (Jn 1:14).

Hallelujah, in the Spirit of Christ, we know that in spite of sin and evil, in spite of the killing fields, we are not alone, Godis-with-us, Emmanuel: the Word became flesh and dwelt amongst us, was crucified, arose from the dead, and will come again. Eros - God's cosmic love - is the energy creating all things, sustaining them, drawing everything together. It is the gracious healing process at the heart of reality, making and remaking connections. Love is happening, and continues to happen in the world. And we are invited - still more, we are called - as heirs of God and joint heirs with Christ to share in his sufferings for the redemption of the world. Putting our ears to the ground, opening the cockles of hearts in acts of respect, vigilance and longsuffering, we are to listen for the cries of the heart - for what is being witnessed to and confessed in and through words, views, and concepts that may be very strange or upsetting - that can lead to the miracle of connection.
What a challenge, what a mission! It is my prayer that we can together go forth with a daring and tender love. And whatever we do, may we do it in the name of Love. Let Love come again and again. Viens, oui, oui. The world is waiting!

\section{Acknowledgements}

The author wishes to acknowledge that he received a KIC grant from the National Research Foundation (NRF) in 2011. The funds received contributed to his conference and travel costs, as well as the page fees for this article.

\section{Competing interests}

The author declares that he has no financial or personal relationship(s) which may have inappropriately influenced him in writing this article.

\section{References}

Bauckham, R., 2002, God and the crisis of freedom: Biblical and contemporary perspectives, Westminster John Knox Press, Louisville.

Coe, J.H. \& Hall, T.W., 2010, Psychology in the Spirit, IVP Academic, Downers Grove.

Derrida, J., 1992, 'Ulysses gramophone: Hear say yes in Joyce', in D. Attridge (ed.), Acts of literature, pp. 253-309, Routledge, New York.

Derrida, J., 1993, Memoirs of the blind, transl. P.-A. Broult \& M. Naas, University of Chicago Press, Chicago.

Gasche, R., 1986, The tain of the mirror, Harvard University Press, Cambridge.

Goleman, D., 2006, Social intelligence, Bantam Books, New York.

Jüngel, E., 1983, God as mystery of the world, Eerdmans, Grand Rapids.

LaCugna, C.M., 1973, God for us, Harper, San Francisco.

LeDoux, J., 1996, The emotional brain, Touchstone, New York.

Levinas, E., 1969, Totality and infinity, transl. A. Lingus, Duquesne University Press, Pittsburgh.

Levinas, E., 1981, Otherwise than being, transl. A. Lingus, Martinus Nijhoff, The Hague.

Marion, J.-L., 1991, God without being, transl. T. Carlson, University of Chicago Press, Chicago.

Marion, J.-L., 1992, 'Christian philosophy and charity', Communio 19(Fall), 463-473.

Olthuis, J.H., 1997, 'Face-to-face: Ethical asymmetry or the symmetry of mutuality?', in J.H. Olthuis (ed.), Knowing other-wise, pp. 131-158, Fordham University Press, New York.

Olthuis, J.H., 2006, The beautiful risk, Wipf \& Stock, Eugene.

Olthuis, J.H., 2008, 'Creatio ex amore', in N. Wirzba \& B. Benson (eds.), Transforming philosophy and religion, pp. 155-170, Indiana University Press, Bloomington.

Smith, J.K.A., 2009, Desiring the kingdom, Baker Academic, Grand Rapids. 